Bull. Chem. Soc. Ethiop. 2012, 26(3), 449-454.

Printed in Ethiopia

ISSN 1011-3924

DOI: http://dx.doi.org/10.4314/bcse.v26i3.14

(C) 2012 Chemical Society of Ethiopia

\title{
ELECTROCATALYTIC REDUCTION OF OXYGEN AT VAPOR PHASE POLYMERIZED POLY(3,4-ETHYLENEDIOXIDETHIOPHENE) MODIFIED GLASSY CARBON ELECTRODE
}

\author{
Berhanu Wondimu and Shimelis Admassie ${ }^{*}$ \\ Department of Chemistry, Addis Ababa University, P. O. Box 1176, Addis Ababa, Ethiopia
}

(Received May 3, 2011; revised June 6, 2012)

\begin{abstract}
We successfully polymerized poly(3,4-ethylenedioxidethiophene) by vapor phase polymerization technique on rotating glassy carbon disk electrode. The catalytic activity of this electrode towards oxygen reduction reaction was investigated and showed remarkable activity. Rotating disk voltammetry was used to study the kinetics of oxygen reduction reaction by plotting Levich, Koutecky Levich and Tafel plots. It was found that the reduction was mixed diffusion and kinetic controlled. The $\mathrm{O}_{2}$ reduction underwent through four electron transfer reaction. The Tafel slope was obtained as $55 \mathrm{mV} / \mathrm{dec}$. The limiting current density was higher by a factor of more than $10^{3}$ times the exchange current density.
\end{abstract}

KEYWORDS: Poly(3,4-ethylenedioxidethiophene), Vapor phase polymerization, Oxygen reduction, Glassy carbon electrode

\section{INTRODUCTION}

One of the difficult situations in the widespread use of alternative renewable energy sources like solar and hydroelectric energy sources for sustainable power generation is the growing energy demand that does not correlate with the actual available energy from these sources. This calls for an efficient means of storing excess energy when the sun is shining or when the weather is good enough to supply the water needed for hydroelectric power plants. Electrochemical energy conversion like fuel cells are most attractive technologies for efficiently storing the excess electrical energy in to chemical fuels and later use it for different applications ranging from powering small portable devices to generating several megawatts of electrical energy for stationary power generation and for transportation purposes [1-4]. Several different types of fuel cells such as polymer electrolyte membrane [5], alkaline [6], phosphoric acid [7], molten carbonate [8], solid oxide [9] and biofuel cells [10] are under development [11].

In all fuel cell devices, the reduction of $\mathrm{O}_{2}$ to $\mathrm{H}_{2} \mathrm{O}$ plays a critical role. The sluggish nature of the oxygen reduction reaction requires an expensive electrocatalyst like platinum. The high cost of platinum is the main reason for keeping consumers from reaping the benefits of the clean energy afforded by fuel cell technology for transportation and stationary power generation applications. Because of this, a vast worldwide research effort is underway to identify and synthesize cheaper electrocatalysts to reduce the amount of platinum loading or completely replace it with non-platinum based catalysts. Materials like clays, zeolites, quinones, anthraquinone and their derivatives, nanotubes and metal nanoparticles alone and in combination with conducting polymers are also under intensive investigations for their catalytic behavior towards oxygen reduction [12-20].

Conducting polymers synthesized electrochemically, chemically as well using vapor phase polymerization techniques found interesting electrocatalytic activity towards oxygen reduction for reducing the amount of platinum loading or completely replace it with cheap and efficient non-platinum based electrocatalysts [21-24]. Particularly, poly(3,4-ethylenedioxythiophene), which is commonly used in organic electronic devices show quite remarkable behavior when synthesized through vapor phase method which results from its high conductivity and we

*Corresponding author. E-mail: shimadm@yahoo.com 
characterized and investigated its potential applications in organic electronics [25-28]. In this study, we report to our knowledge for the first time the electrocatalytic behavior of this material for oxygen reduction at rotating glassy carbon disk electrode.

\section{EXPERIMENTAL}

The glassy carbon rotating disk electrode of $0.0707 \mathrm{~cm}^{2}$ area was first polished to a mirror finish using $0.05 \mathrm{~mm}$ alumina prior to each experiment. The VPP PEDOT was prepared on the polished glassy carbon electrode following similar procedures reported earlier [25-28]. Briefly, $0.585 \mathrm{~mL}$ of pyridine was added to $20 \mathrm{~mL}$ of Baytron C $40 \%$ iron(III) tosylate in butanol $(\mathrm{H}$. C. Starck Newton, MA) and the mixture was then spin coated on a polished glassy carbon electrode for $1 \mathrm{~min}$ at $2500 \mathrm{rpm}$. The sample was then inverted and transferred to a reaction chamber where 3,4-ethylenedioxythiophene was allowed to evaporate at $65{ }^{\circ} \mathrm{C}$ for $30 \mathrm{~min}$, allowing the polymerization reaction to occur directly on the electrode surface. Finally, the sample was left at room temperature for 30 min before rinsing the unreacted oxidant with ethanol. The average film thickness we obtained when vapour phase synthesis was made on different substrates under these conditions was about $120 \mathrm{~nm}$ [26].

For the electrosynthesis of PEDOT, a $0.01 \mathrm{M}$ EDOT monomer was dissolved in a $0.1 \mathrm{M}$ tetrabutylammonium tetrafluoroborate $\left(\mathrm{Bu}_{4} \mathrm{NBF}_{4}\right)$ in acetonitrile as the solvent. The EDOT was then electropolymerized on the dried GC by running cyclic voltammetry from 0.0 to $1.3 \mathrm{~V}$ (versus $\mathrm{Ag} / \mathrm{AgCl}$ ) for ten cycles. After electropolymerization, the PEDOT modified GC electrode was carefully washed with acetonitrile. Then the modified electrode was cycled between -0.8 to $0.8 \mathrm{~V}$ in monomer free $0.1 \mathrm{M} \mathrm{Bu}_{4} \mathrm{NBF}_{4} /$ acetonitrile solution until stable film is obtained.

Cyclic voltammetric investigations and rotating disk experiments were carried out using Epsilon electrochemical workstation. A three-electrode system consisting of VPP PEDOT/GCE or ECP PEDOT/GC as a working electrode, a $\mathrm{Ag} / \mathrm{AgCl}$ reference electrode and a platinum wire counter electrode were used for the electrochemical measurements.

\section{RESULTS AND DISCUSSION}

Figure 1 shows the cyclic voltammograms of the vapor phase polymerized (VPP) PEDOT modified glassy carbon electrode (GCE), and electrochemically polymerized (ECP) PEDOT modified GCE and bare GCE in oxygen and argon saturated $0.5 \mathrm{M} \mathrm{H}_{2} \mathrm{SO}_{4}$ solution, respectively. The comparison of the electrocatalytic activity of the different electrodes toward oxygen reduction revealed that the oxygen reduction potential is shifted to more positive value and the peak current is highest in the VPP PEDOT in oxygen saturated $0.5 \mathrm{M} \mathrm{H}_{2} \mathrm{SO}_{4}$ solution (Figure 1). No significant electrocatalytic activity is observed for the ECP PEDOT modified GCE in oxygen saturated $0.5 \mathrm{M} \mathrm{H}_{2} \mathrm{SO}_{4}$ solution as reported earlier by other groups [29].

Rotating disk voltammograms for VPP PEDOT modified GCE in oxygen saturated $0.5 \mathrm{M}$ $\mathrm{H}_{2} \mathrm{SO}_{4}$ at different rotation speeds (100-3200 rpm) are shown in Figure 2. The currents associated with $\mathrm{O}_{2}$ reduction begins to flow around $-0.1 \mathrm{~V}(\mathrm{Ag} / \mathrm{AgCl})$ and exhibit plateaus at around $-0.63 \mathrm{~V}(\mathrm{Ag} / \mathrm{AgCl})$. The diffusion limiting current was observed and increased with increasing rotation speed. The current density under pure argon atmosphere is also shown and is independent of the rotation speed. 


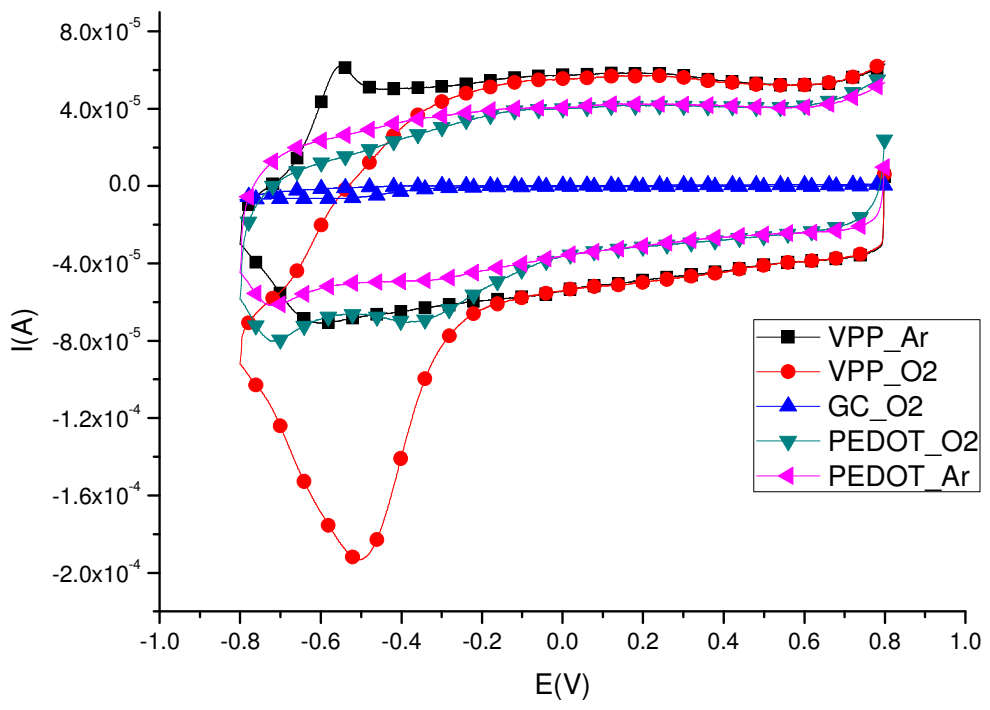

Figure 1. Comparative cyclic voltammograms of the modified and bare electrodes in oxygen saturated $0.5 \mathrm{M} \mathrm{H}_{2} \mathrm{SO}_{4}$. Scan rate $100 \mathrm{mV} / \mathrm{s}$.

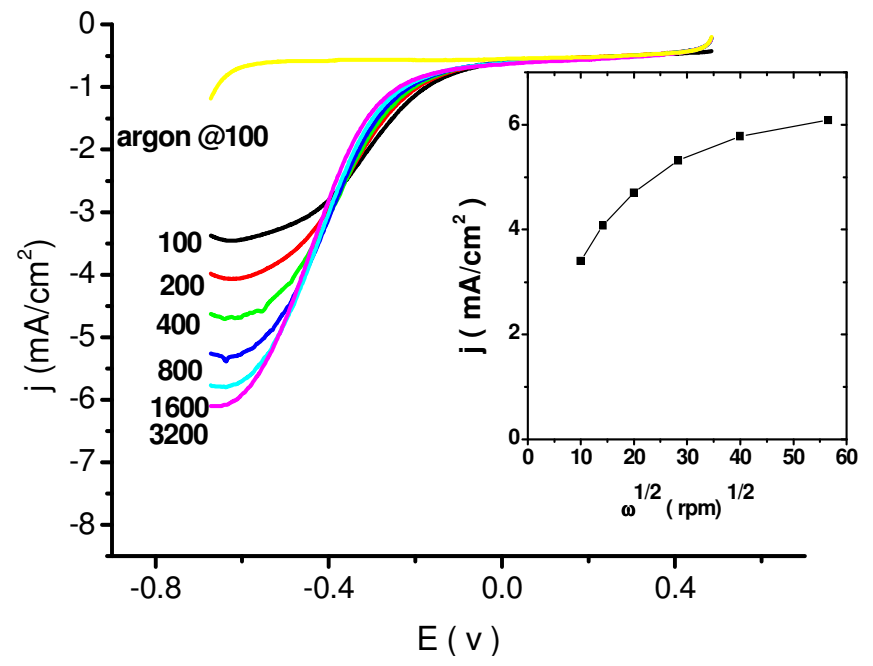

Figure 2. Rotating disk voltamograms at different rotation speeds for $\mathrm{O}_{2}$ reduction on a VPP PEDOT modified GCE in oxygen and Argon saturated $0.5 \mathrm{M} \mathrm{H}_{2} \mathrm{SO}_{4}$; respectively, at scan rate of $10 \mathrm{mV} / \mathrm{s}$ between potential of $0.4 \mathrm{~V}$ to $-0.672 \mathrm{~V}$ (versus $\mathrm{Ag} / \mathrm{AgCl}$ ). The inset shows Levich plot of limiting current at potential of $-0.63 \mathrm{~V}$ (versus $\mathrm{Ag} / \mathrm{AgCl}$ ) for $\mathrm{O}_{2}$ saturated $0.5 \mathrm{M} \mathrm{H}_{2} \mathrm{SO}_{4}$ at VPP PEDOT modified GCE.

The rotating disk electrode (RDE) data were analyzed using the Levich and the KouteckyLevich equations. The Levich equation is expressed as equation 1: 
$I_{l}=0.62 n F A C{ }_{o} D^{\frac{2}{3}} v^{-\frac{1}{6}} \omega^{\frac{1}{2}}$

where $\mathrm{n}$ is the number of electrons, $\mathrm{F}$ is the Faraday constant $\left(96485 \mathrm{Cmol}^{-1}\right), \mathrm{A}$ is the electrode area $\left(0.0707 \mathrm{~cm}^{2}\right), \mathrm{C}_{\mathrm{o}}$ is concentration of $\mathrm{O}_{2}\left(1.1 \times 10^{-6} \mathrm{~mol} / \mathrm{cm}^{3}\right)$, D is the diffusion coefficient $\left(1.4 \times 10^{-5} \mathrm{~cm}^{2} / \mathrm{s}\right)$ of oxygen, $v$ is kinematic viscosity of $\mathrm{O}_{2}\left(1.1 \times 10^{-2} \mathrm{~cm}^{2} / \mathrm{s}\right)$ taken from the literature value and $\omega$ angular velocity (in rpm) [30]. The nonlinear Levich plot and the highest value of the current plateau reached for oxygen reduction at VPP PEDOT modified GCE in an $\mathrm{O}_{2}$ saturated $0.5 \mathrm{M} \mathrm{H}_{2} \mathrm{SO}_{4}$ solution (Figure 2 insert), suggests that the oxygen reduction is mixed diffusion and kinetic controlled reaction [31].

The kinetic contribution to the current is given by equation 2 :

$I_{k}=n F A C_{o} k_{o} \exp \left(\frac{-\alpha n F\left(E-E_{o}\right)}{R T}\right)=n F A k_{f} C_{o} \Gamma$

where $\mathrm{k}_{\mathrm{o}}$ is the standard heterogeneous rate constant, $\mathrm{k}_{\mathrm{f}}$ is the heterogeneous rate constant, $\Gamma$ is the surface coverage by active species, $\mathrm{E}_{\mathrm{o}}$ is the formal potential, $\mathrm{E}$ is electrode potential, $\mathrm{T}$ is temperature and $\mathrm{R}$ is gas constant. The electrode current for case in mixed transport-kinetic control is described by the above equation. The combination of these equations produces the so called Kouteky-Levich equation 3:

$$
\frac{1}{i}=\frac{1}{i_{k}}+\frac{1}{i_{l}}=\frac{1}{n F A k_{f} C \Gamma}+\frac{1}{0.62 n F A C_{o} D^{\frac{2}{3}} v^{-\frac{1}{6}} \omega^{\frac{1}{2}}}
$$

The plot of $\frac{1}{i_{l}}$ vs $\frac{1}{\omega^{\frac{1}{2}}}$ for constant value of $\mathrm{k}_{\mathrm{f}}$ i.e. fixed $\eta$ are predicted to generate straight line having slope proportional to $1 / \mathrm{n}$ and intercept proportional to $\frac{1}{k_{f}}$ [31].

The Kouteky-Levich plot (current density corrected from the background yielded straight lines with the intercept corresponding to the inverse of the kinetic current.

The data from the slope of Koutectky-Levich plot at $-0.63 \mathrm{~V}$ was also used to calculate the number of electrons and found to be $n=3.12$. The slope of the Koutectky-Levich plot is close to the theoretical value of the four electron reduction $\mathrm{O}_{2}$ directly to $\mathrm{H}_{2} \mathrm{O}$. This confirms that the oxygen reduction reaction at the VPP PEDOT modified GCE in oxygen saturated $0.5 \mathrm{M} \mathrm{H}_{2} \mathrm{SO}_{4}$ solution is not a two electron reaction via the formation of $\mathrm{H}_{2} \mathrm{O}_{2}$. Similar results are obtained for carbonized polyaniline nanostructures and micro/mesoporous conducting nitrogen-containing carbon nanorods/nanotubes with high surface area, and excellent electrocatalytic activity for the oxygen reduction reaction, which also belong to the classes of non-precious catalysts as VPP PEDOT [32, 33].

The intercept at the origin of the Koutecky-Levich plot gives the inverse of the kinetic current $\mathrm{I}_{\mathrm{k}}$ as a function of potential. The Tafel slope $(\mathrm{b}=55 \mathrm{mV} / \mathrm{dec})$ and the exchange current $\left(\mathrm{I}_{\mathrm{o}}=1.48 \times 10^{-7} \mathrm{~A}\right)$ were determined by plotting (Figure 3) the potential E versus $\ln \left|\frac{I_{l} * I_{k}}{I_{l}-I_{k}}\right|$ using the equation 4 [34]:

$E=E_{e q}-b\left[\ln \left(\frac{j_{l}}{j_{o}}\right)+\ln \left|\frac{j_{k}}{j_{l}-j_{k}}\right|\right]$

where $I_{1}$ is the limiting current $\left(5.035 \times 10^{-4} \mathrm{~A}\right)$. 


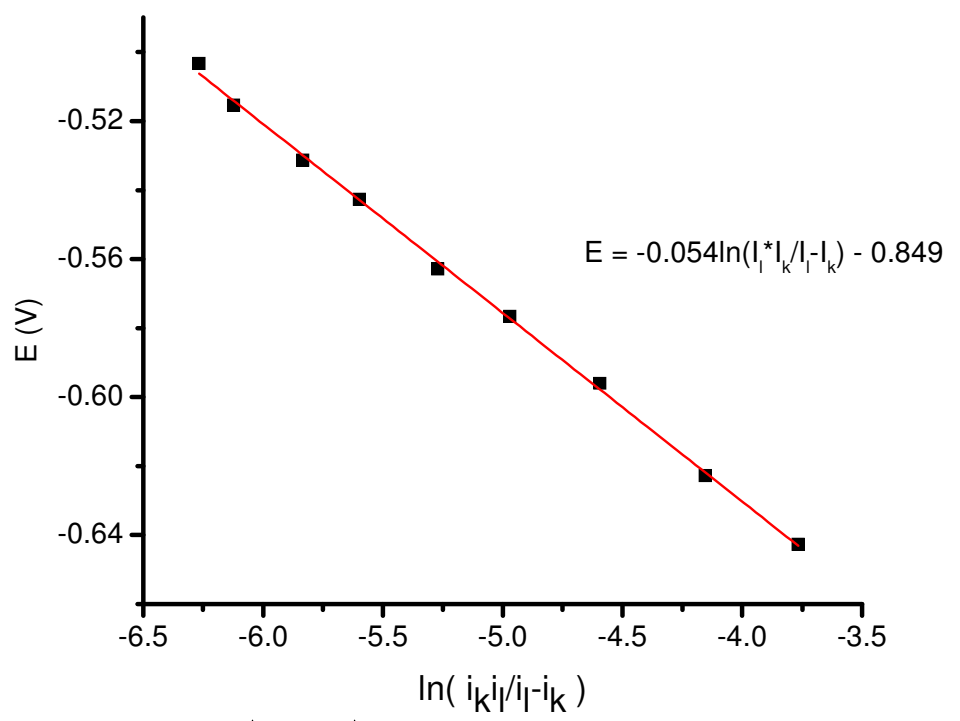

Figure 3. Plot of E versus $\ln \left|\frac{I_{l} * I_{k}}{I_{l}-I_{k}}\right|$ for oxygen reduction at VPP-PEDOT modified GCE in oxygen saturated $0.5 \mathrm{M} \mathrm{H}_{2} \mathrm{SO}_{4}$.

The value of the Tafel slope obtained $\left(b=55 \mathrm{mv} \mathrm{dec}^{-1}\right)$ indicates Temkin adsorption isotherm [35-37]. The limiting current, $I_{1}$ is much higher (by a factor of more than $10^{3}$ times) than that of the exchange current, $I_{o}[34,31]$.

\section{CONCLUSIONS}

The electrocatalytic reduction of oxygen was studied on the VPP-PEDOT modified GCE using cyclic voltammetry and rotation disk voltammetry. The VPP-PEDOT modified GCE was found to have significant effect on the catalytic activity. The kinetic parameters like $I_{0}, I_{1}$ and Tafel slope were evaluated. The results showed that VPP-PEDOT was a promising catalyst and can also serve as a catalyst support of platinum or non-platinum based metals for oxygen reduction reaction.

\section{REFERENCES}

1. Haile, S.M. Acta Mater. 2003, 51, 5981.

2. Haile, S.M.; Helmolt, R.V.; Eberle U. J. Pow. Sour. 2008, 165, 833.

3. Lewis, N.S. Science 2007, 315, 798.

4. Goff, A.L.; Artero, V.; Jousselme., B.; Tran, P. D.; Guilet, N.; Metaye, R.; Fihri, A.; Palain, S.; Fontecave, M. Science 2009, 326, 1384.

5. Venkateswara, R.; Viswanathan, B. J. Phys. Chem. C 2010, 114, 8661.

6. Li, X.; Liu, G.; Popov, N.G. J. Pow. Sour. 2010, 195, 6373.

7. Neergat, M.; Shukla, A. K. J. Pow. Sour. 2001, 102, 317.

8. Janowitz, K.; Kah, M.; Wendt, H. Electrochim. Acta 1999, 45, 1025.

9. Liu, B.; Gu, Y.; Kong, L.; Zhang, Y. J. Pow. Sour. 2008, 185, 946.

10. Martin, E.; Tartakovsky, B.; Savadogo, O. Electrochim. Acta 2011, 58, 58. 
11. Srinvassa, S.; Fuel Cells: From Fundamentals to Applications, Springer: New York; 2006; $\mathrm{p} 442$.

12. Zhou, Q.; Li, C.M.; Li, J.; Cui, X.; Gervasio, D. J. Phys. Chem. C 2007, 111, 11216.

13. Sljukic, B.; Banks, C.E.; Mentus, S.; Compton, R.G. Phys. Chem. Chem. Phys. 2004, 6, 992.

14. Sarapuu, A; Helstein, K.; Vaik, K. Schiffrin, J.D; Tammeveski, K. Electrochim. Acta 2010, $55,6376$.

15. Olson, T.S.; Pylypenko, S.; Atanassov, P. J. Phys. Chem. C 2010, 114, 5049.

16. Rajapakse, R.M.G.; Murakami, K.; Bandara, H.M.N.; Rajapakse, R.M.M.Y.; Velauthamurti,

K.; Wijeratne, S. Electrochim. Acta 2010, 55, 290.

17. Zhang, R.; Ma, J.; Wang, W.; Wang, B.; Li, R. J. Electroanal. Chem. 2010, 643, 31.

18. Mamuru, S.A.; Ozoemena, K.I.; Fukuda, T.; Kobayashi, N.; Nyokong, T. Electrochim. Acta 2010, 55, 6367.

19. Ang, S-Y.; Walsh. D. J. Pow. Sour. 2010, 195, 2557.

20. Mirkhalaf, F.; Schiffrin, D.J. Langmuir 2010, 26, 14995.

21. Jenson, B.W.; Jenson, O.W.; Forsyth, M.; MacFarlane, D.R. Science 2008, 321, 671.

22. Zhang, W.; Chen, J.; Wagner, P.; Swiegers, G.F.; Wallace, G.G. Electrochem. Commun. 2008, $10,519$.

23. Millan, W.M.; Smit, M.A. J. Appl. Polym. Sci. 2009, 112, 2959.

24. Kumar, S.A.; Chen, S.M. J. Mol. Catal. A: Chemic. 2007, 278, 244.

25. Tong, T.; Babatope, B.; Admassie, S.; Meng, J.; Akwogu, O.; Akande, W.; Soboyejo, W.O. J. Appl. Phys. 2009, 106, 083708.

26. Padmalekha, K.G.; Admassie, S. Synth. Met. 2009, 159, 1885.

27. Gadisa, A.; Tvingstedt, K.; Admassie, S.; Lindell, L.; Crispin, X.; Andersson, M.R.; Salaneck, W.R.; Inganäs, O. Synth. Met. 2006, 156, 1102.

28. Admassie, S.; Zhang, F.; Manoj, A.G.; Svensson, M.; Anderson, M.R.; Inganäs, O. Sol. Energ. Mat. Sol. C 2005, 90, 133.

29. Khomenko, V.G.; Barsukov, V.Z.; Katashinskii, A.S. Electrochim. Acta 2005, 50, 1675.

30. Ponce, Y.G.; Nuñez, G.A.; Vante, N.A. Electrochem. Commun. 2006, 8, 1487.

31. Bard, A.J.; Faulkner, L.R. Electrochemical Methods, Fundamental and Applications, 2nd ed., Wiley: New York; 2001; p 341.

32. Gavrilov, N.; Vujkovic, M.; Pasti. A.I.; Marjanovic, G.C.; Mentus, S.V. Electrochim. Acta 2011, 56, 9197.

33. Janosevic, A.; Pasti, I.; Gavrilov, N.; Mentus, S.; Ciric-Marjanovic, G.; Krstic, J.; Stejskal J. Synth. Met. 2011, 161, 2179.

34. Coutanceau, C.; Croissant, M.J.; Napporn, T.; Lamy, C. Electrochim. Acta 2000, 46, 579.

35. Sepa, D.B.; Vojnovic, M.V.; Vracar, L.J.M.; Damjanovic, A. Electrochim. Acta 1986, 36, 91.

36. Sepa, D.B.; Damjanovic, A. Electrochim. Acta 1980, 25, 1491.

37. Sepa, D.B.; Vojnovic, M.V.; Damjanovic, A. Electrochim. Acta 1981, $26,781$. 